\title{
The Philippine Engagement with Paulo Freire
}

\section{Franz Giuseppe F. Cortez}

\begin{abstract}
This paper is mainly a provisional survey of the engagement of the Filipinos with the thoughts of Paulo Freire, a Brazilian educator and philosopher. It presents first the main tenets of Freire's liberating pedagogy. Then, it explores the Filipinos' engagement with his ideas. Then, it gives some observations on the said engagement. Finally, it suggests a possible way on how philosophical researches in the Philippines can continually appreciate the relevance of Freire's liberating pedagogy especially in relating it to a form of Filipino philosophy that is involved in a critique of the society.
\end{abstract}

Keywords: Freire, liberating pedagogy, Philippine education, Filipino philosophy

\section{Freire and his Liberating Pedagogy}

$\mathrm{P}$ aulo Freire (1921-1997) is a Brazilian educator, activist and philosopher during the second half of the $20^{\text {th }}$ century. ${ }^{1}$ Even though he authored several works spread over a period of more than 30 years, he is basically known by many for writing Pedagogy of the Oppressed, a book that positions education in relation to the issues of oppression and domination. The book is also considered to be one of the pillars of what later on would be called as Critical Pedagogy.2 There are at least five important elements of Freire's liberating pedagogy: nonneutrality, critique, dialogue, praxis and concern for transformation.

${ }^{1}$ For a detailed account of his life, see the following: Denis E. Collins, Paulo Freire: His Life, Works and Thoughts (New York: Paulist Press, 1977), 5-24; Paul V. Taylor, The Texts of Paulo Freire (Buckingham \& Philadelphia: Open University Press, 1993), 12-33; John L. Elias, Paulo Freire: Pedagogue of Liberation (Florida: Krieger Publishing Company, 1994), 1-16.

2 See Joe L. Kincheloe, Critical Pedagogy Primer, $2^{\text {nd }}$ ed. (New York: Peter Lang Publishing Inc., 2008), 69-75.

(c) 2013 Franz Giuseppe F. Cortez

http://www.kritike.org/journal/issue 13/cortez december2013.pdf

ISSN 1908-7330

$(\mathrm{cc})$ BY-NC 
Freire contends that education is not neutral. He states: "The first proposition that I advance and the most basic one is that there is nothing like neutral education. Education is a political act. It is impossible to analyze education without analyzing the problem of power." ${ }^{3}$ The American theologian Richard Shaull explains nonneutrality in these words:

There is no such thing as a neutral educational process. Education either functions as an instrument which is used to facilitate the integration of the younger generation into the logic of the present system and bring about conformity to it, or it becomes 'the practice of freedom', the means by which men and women deal critically and creatively with reality and discover how to participate in the transformation of their world. ${ }^{4}$

On the other hand Henry Giroux, a North American critical educator states that "[e]ducation represents in Freire's view both a struggle for meaning and a struggle over power relations." 5 With the inherent politics of all educational processes, Freire further maintains that the educator must choose whether his politics favors the interest of the oppressor or that of the oppressed. ${ }^{6}$

If a liberating pedagogy consciously supports the interest of the oppressed and the dominated, then it must problematize the various forms of domination inside the school and in the society at large. This is the element of critique. Its aim is the emergence and development of a critical consciousness among the participants of the pedagogical process. Freire calls this process conscientizacao, usually translated into English as conscientization. ${ }^{7}$ It is defined as "learning to perceive social, political, and

\footnotetext{
3 Paulo Freire, Education for Liberation: Addresses by Paulo Freire (Bangalore: Ecumenical Christian Centre, 1975), 17-18.

${ }^{4}$ Richard Shaull, foreword to Pedagogy of the Oppressed, by Paulo Freire, trans. by Myra Bergman Ramos (New York: The Continuum Publishing Corporation, 1984), 15.

${ }^{5}$ Henry Giroux, Teachers as Intellectuals: Towards a Critical Pedagogy of Learning (Massachusetts: Bergin \& Garvey, 1988), 110.

${ }^{6}$ Paulo Freire and Ira Shor, A Pedagogy for Liberation: Dialogues on Transforming Education, trans. by Connecticut: Bergin \& Garvey Publishers, Inc., 1987), 46.

7 Freire admits that he is not the first to use the term. He attributes its initial popularity in Europe and North America to the works and travels of Dom Helder Camara, the Bishop of Recife at that time. See Paulo Freire, "Conscientizing as a Way of Liberating," in Third World Liberation Theologies: A Reader, ed. by Deanne William Ferm (New York: Orbis Books, 1986), 5-6. Furthermore, Taylor reports that Freire admits stopping using the term since the early 1970's "because the word was so corrupted in Latin America and in the States. It does not mean that I reject the process which the word means." See Taylor, "The Texts of Paulo Freire," 52.
} 
economic contradictions, and to take action against the oppressive elements of reality." 8 In his other writings, Freire explains conscientization as a kind of education that involves both reading the word and reading the world. ${ }^{9}$ Technical expertise and political literacy go hand in hand. Freire makes it clear that in the context of classroom experience, one cannot be sacrificed for the other. In Pedagogy of the City, he clarifies: "What would be wrong, and what I have never suggested should be done, is to deny learners their right to literacy because of the necessary politicization there would not be time for literacy in the strict sense of the term. Literacy involves not just reading the word but reading the world." 10

Dialogue is another important element of Freire's liberating pedagogy. He describes dialogue as "the encounter between [persons], mediated by the world, in order to name the world."11 He observes that generally speaking education is suffering from narration sickness. ${ }^{12}$ It is characterized by a culture of silence or mutism. ${ }^{13}$ It is largely based on what Freire calls a banking education which is fundamentally monological. ${ }^{14}$ In glaring contradiction with the banking education is what Freire calls the problem-posing education where the teacher does not deposit fixed knowledge to the students but reality is posed as a problem for the students to think about, question, critique and transform. "Authentic education is not carried on by " $\mathrm{A}$ " for " $\mathrm{B}$ " or by " $\mathrm{A}$ " about " $\mathrm{B}$," but rather by " $\mathrm{A}$ " with " $\mathrm{B}$," mediated by the world-a world which impresses and challenges both parties, giving rise to views or opinions about it."15 This education "consists in acts of cognition, not transferrals of information."16 The "I" who can know interacts with a "You" that can also know, regarding an aspect of the world that can be known. Both the teacher and the students are knowing Subjects reflecting on a knowable object which is the world.

The fourth element of Freire's liberating pedagogy is praxis. He defines praxis as "reflection and action upon the world in order to transform

${ }^{8}$ Freire, Pedagogy of the Oppressed, 19.

9 See Paulo Freire and Donaldo Macedo, Literacy: Reading the Word $\mathcal{E}$ the World (Massachusetts: Bergin \& Garvey Publishers, Inc., 1987).

${ }^{10}$ Paulo Freire, Pedagogy of the City (New York: Continuum Press, 1993), 59.

${ }^{11}$ Freire, Pedagogy of the Oppressed, 76.

12 Ibid., 57.

${ }_{13}$ Freire, Education as the Practice of Freedom, 24. For a thorough explanation of the concept of culture of silence, see also Paulo Freire, "Cultural Action and Conscientization," in Harvard Educational Review 40:3 (August 1970).

${ }^{14}$ In Pedagogy of the Oppressed, Freire explains that a monological education happens when the teacher is simply a narrator of knowledge while the students quietly, meekly and passively accept, memorize and restate what the teacher says. See Freire, Pedagogy of the Oppressed, 57ff.

${ }^{15} \mathrm{Ibid} ., 82$.

${ }^{16} \mathrm{Ibid} ., 67$.

(c) 2013 Franz Giuseppe F. Cortez

http://www.kritike.org/journal/issue 13/cortez december2013.pdf

ISSN 1908-7330

(cc) BY-NC 
it."17 Certainly, it has a mark of Marxism. Ronald Glass, another Freirean scholar, affirms that it is already a given that at the center of Freire's liberating pedagogy is Marx's philosophy of praxis. ${ }^{18}$ For Freire, in order to attain genuine and meaningful social transformation, pure reflection/verbalism and pure action/activism by themselves are insufficient. ${ }^{19}$ The insufficiency of one is complemented by the other so that the dialectic is what Paul Taylor calls as "active reflection and reflective action." 20 Praxis combines "perception of reality" and "critical intervention" upon reality. ${ }^{21}$

Transformation is another element of Freire's liberating pedagogy. It means that the concern of the critical educator is to link the classroom discourse to the larger dream of creating a more just, humane and free society. Freire says in Cultural Action for Freedom: "As an ever calling forth the critical reflection of both the learners and educators, the [educative] process must relate speaking the word to transforming reality, and to man's role in this transformation." 22 And then, in Pedagogy of the Oppressed, he says: "In order for the oppressed to be able to wage the struggle for their liberation, they must perceive the reality of oppression not as a closed world from which there is no exit, but as a limiting situation which they can transform." 23 Stephen Brookfield, in his article that relates the significance of ideology critique to transformative learning, says that Freire's educational theory is one among those theories that do not end with a critique of ideology but "also contains within it the promise of social transformation." 24 For his part, the American Jesuit scholar Denis E. Collins says that Freire's political pedagogy repeatedly pleads for an affirmation "that pedagogy can make a difference in creating a more humane world" and "that liberationist educators can continue to play a major role in attaining that goal." 25 Freire says in his dialogical book with Donaldo Macedo: "The progressive educator rejects the dominant values imposed on

17 Ibid., 36 and 66.

18 Ronald Glass, "On Paulo Freire's Philosophy of Praxis and the Foundations of Liberation Education," in Educational Researcher, 30:2 (March 2001), 15-25, 16.

${ }^{19}$ Freire, Pedagogy of the Oppressed, 75-76.

${ }^{20}$ Taylor, Texts of Freire, 56.

${ }^{21}$ Freire, Pedagogy of the Oppressed, 37.

${ }^{22}$ Freire, "Cultural Action for Freedom," in Paulo Freire, The Politics of Education: Culture, Power and Liberation, trans. by Donaldo Macedo (Massachusetts: Bergin \& Garvey Publishers, Inc., 1985), 51.

${ }^{23}$ Freire, Pedagogy of the Oppressed, 34.

${ }^{24}$ Stephen D. Brookfield, "Transformative Learning as Ideology Critique," in Jack Mezirow \& Associates, Learning as Transformation: Critical Perspectives on a Theory in Progress (San Francisco, California: Jossey-Bass, 2000), 129.

${ }^{25}$ Denis E. Collins, "From Oppression to Hope: Freire's Journey towards Utopia," in Anthropology \& Education Quarterly, 29:1 (March 1998), 122.

(C) 2013 Franz Giuseppe F. Cortez http://www.kritike.org/journal/issue 13/cortez december2013.pdf ISSN 1908-7330 


\section{PAULO FREIRE}

the school because he or she has a different dream, because he or she wants to transform the status quo." 26

But Freire is not naïve and he does not delude himself as regards the power of the school to transform the social structures. He says that conscientization (or education, for that matter) is not a panacea or a magical pill that would immediately cure the ills of the society. ${ }^{27}$ In fact, the critical educator must be aware of the many limitations of the classroom even for individual transformation. Freire contends: "If teachers don't think in terms of phases, levels, and gradations in a long process of change, they may fall into a paralyzing trap of saying that everything must be changed at once or it isn't worth trying to change anything at all. Looking only for big changes, teachers may lose touch with the transformative potential in any activity." 28 For Freire, education is not sufficient to transform the oppressive structures of the society. But still, education is essential for this undertaking.

To summarize, Freire's liberating pedagogy can be described as a nonneutral educational praxis that is anchored on dialogue and critique aiming for a transformed society which is more just, humane and free.

\section{Philippine Engagement with Freire's Thoughts}

It can be assumed that Freire's thoughts would find an appeal in a country like the Philippines that has a long history of oppression and domination. The American activist and writer Jonathan Kozol, in his foreword to one of Freire's books, would refer to this as "a shared heritage of servitude." 29 Thus, it is not coincidental that Freire's most famous book, Pedagogy of the Oppressed, reached the Philippine shores in a time of social and political upheaval during the 1960s and 1970s. In the global scene, it was the time of anti-colonial revolutions, liberation theology, Vatican II, Vietnam War, student activism, civil rights movements, and women's liberation movements. ${ }^{30}$ In the Philippines, there was also social and political restlessness. Nicanor Tiongson, a leading Filipino critic and academician, describes that era of Philippine history in these words:

\footnotetext{
${ }^{26}$ Freire and Macedo, Literacy: Reading the Word \& the World, 126.

27 Paulo Freire, Pedagogy of Freedom: Ethics, Democracy and Civic Courage, trans. by Patrick Clarke (Maryland: Rowman \& Littlefield Publishers, Inc., 1998), 55.

${ }^{28}$ Freire and Shor, A Pedagogy for Liberation, 35.

${ }^{29}$ Jonathan Kozol, foreword to Pedagogy in Process: The Letters to Guinea-Bissau, by Paulo Freire (New York: The Seabury Press, 1978), 3.

30 Karina Constantino-David, "From the Present Looking Back: A History of Philippine NGOs," in Organizing for Democracy: NGOs, Civil Society, and the Philippines State, edited by Sidney Silliman \& Lela Garner Noble (Quezon City: Ateneo de Manila University Press, 1998), 33.
}

(c) 2013 Franz Giuseppe F. Cortez http://www.kritike.org/journal/issue 13/cortez december2013.pdf ISSN 1908-7330 
The decades of the 60 's and 70 's was marked by a passionate attempt on the part of the intelligentsia and the masses to rethink the whole structure of Philippine society. The presence of Americans on the Philippine economy, the feudal structure of land ownership in the country, as well as the corruption of government, and the object of plight of the masses of workers and peasants, were all exposed. Demonstrations protesting the anomalies and injustice of Philippine society became more and more frequent and cultural organizations sprang from the ranks of the students and workers which sought to help in the general call of politicizing the masses." ${ }^{31}$

This political and social unrest is best typified by what is now famously known as the "First Quarter Storm," referring to the first quarter of 1970 characterized by a chain of militant protests, student rallies and violent clashes between government forces and the demonstrators. ${ }^{32}$ John J. Carroll, a Jesuit priest and an American sociologist based in the Philippines, says that the First Quarter Storm is "an event triggered by worsening economic conditions, inflation resulting from massive spending on the 1969 election, increasing misery among the poor, and ostentatious consumption among the wealthy." 33 Carroll notes further that in the beginning years of 1970s, many student activists engaged themselves in the works of some radical thinkers whose short list of names included Paulo Freire. ${ }^{34} \mathrm{He}$ recalls: "Side by side with the 'little red book' of Mao and Philippine Society and Revolution of Jose Maria Sison, student activists devoured and passionately debated the works of Gustavo Gutierrez and other Latin American liberation theologians, Paulo Freire's Pedagogy of the Oppressed, and Saul Alinsky's Reveille for Radicals and Rules for Radicals." 35

But the encounter with the thoughts of these radical thinkers was not confined to the four walls of the classroom and to armchair reflections.

\footnotetext{
31 Nicanor Tiongson, "What is Philippine Drama?," in IBON Teacher's Manual on Philippine History (Manila: IBON Databank Philippines, Inc., 1985), 80.

32 Nick Joaquin, Manila, My Manila: A History for the Young (Manila: The City of Manila, 1990), 216-217.

${ }^{33}$ John Carroll, S.J., "Philippine NGOs Confront Urban Poverty," in Sidney Silliman \& Lela Noble, eds., Organizing for Democracy: NGOs, Civil Society, and the Philippines State (Quezon City: Ateneo de Manila University Press, 1998), 115.

34 Pedagogy of the Oppressed was originally published in Portuguese in 1968. Its first English publication was in 1970, the year that coincides with the First Quarter Storm.

${ }^{35}$ Carroll, “Philippine NGOs Confront Urban Poverty," 115.
} 
The different groups of activists and progressive churchpeople saw at once the applicability of Freire's educational thought and practice in the field of community organizing and popular education. In an article written by Reynaldo Ty, a Filipino-Chinese scholar, he mentions that during the height of Martial Law, Paulo Freire's "action-reflection-action" model was already used by some clandestine militant leaders in facilitating "human rights popular education workshops for churchpeople" to advance national and social liberation. ${ }^{36}$ He further notes that these churchpeople did not see any contradiction in combining the thoughts of Marx and Christianity, a paradigm that Freire himself would not find strange. ${ }^{37}$ Ty says: "Metaphorically, Moses, Jesus, Mary, Marx, and Freire indeed broke bread here in the Philippine revolutionary context." 38

In a collection of reflections of the leading non-government organization (NGO) workers in the Philippines, Margarita Lopa notes that Freire's paradigm for literacy and consciousness-raising influenced sociopolitical organizing in the Philippines during the 1970s. "Employing the frameworks of Saul Alinsky, Paulo Freire, and Karl Marx, we continued to build people's organizations in communities such as those in Tondo in Manila, and Bukidnon in the South. People came together in massive mobilizations in support of numerous causes such as land and shelter, agrarian reform and human rights, and issues such as the rice crisis. ${ }^{39}$

Another veteran NGO person Karina Constantino-David discloses: "[Philippine Ecumenical Committee for Community Organization] expanded its rural and urban organizing efforts, enriching its initial Saul Alinsky framework with snatches of Paulo Freire, liberation theology, Marxism, and structural analysis." 40 G. Sidney Silliman, a political science teacher, also emphasizes how the Filipino community organizers would localize the foreign theories of Freire and Alinsky. ${ }^{41}$ "The teachings of Saul

\footnotetext{
${ }^{36}$ Rey Ty, "Where Moses, Jesus, Mary, Marx, and Freire Share Rice and Fish at the Table: Post-Colonial Christians, Theology of Struggle, and National Liberation in the Philippines" in Michael L. Rowland, ed. Proceedings of 27th Annual Midwest Research-to-Practice Conference in Adult, Continuing, Community and Extension Education (Bowling Green: Western Kentucky University), 222. Accessed August 24, 2012, <http://academia.edu/ Documents/in/Theology_of_Struggle> .

${ }^{37}$ Freire once quipped: "God has led me to the people... The people led me to Marx." See Robert Mackie, ed. Literacy and Revolution: The Pedagogy of Paulo Freire (New York: Continuum Publishing, 1981), 126.

${ }^{38} \mathrm{Ty}$, "Post-Colonial Christians," 222.

39 Margarita Lopa, Singing the Same Song: Reflections of Two Generations of NGO Workers in the Philippines (Quezon City: ANGOC \& PHILDHRRA, 1995), 46.

40 Constantino-David, "From the Present Looking Back: A History of Philippine NGOs," 33.

${ }^{41}$ Saul Alinsky is an American community development worker and author of the famous book Rules for Radicals (1971). For a detailed discussion of his thoughts, see Mike Seal,
} 
Alinsky and Paulo Freire (elaborated and indigenized in the Philippine context) are thoroughly integrated into the community organizing doctrine of the social development NGOs." 42 Then, in another essay, Silliman and Lela Garner Noble note that Vatican II's theological discourse on movement for social change confirms the essential thoughts of Freire on the importance of consciousness-raising among the poor. ${ }^{43}$

Even up to the 1980s and the last years of Marcos' rule, the Freirean approach was used in community organizing. In a book that explores the reception and influence of Freire's thoughts and his continuing relevance today, the Freirean scholar Daniel Schugurensky mentions a case of Filipino teachers inspired by Pedagogy of the Oppressed. Schugurensky reports:

In the last two decades, many people who I barely knew revealed to me, unprompted, that the work of Freire had been tremendously influential in their educational ideas and practices, and called my attention to community projects inspired by Freire's approach that are often unknown outside of their immediate milieu...a woman from the Philippines recalled her involvement - with a group of teachers inspired by Pedagogy of the Oppressed - in a communitybased pre-school and popular education project in the mid-1980s that was welcomed by the community despite its fear of the Marcos dictatorship. ${ }^{44}$

Freire's importance has continued to be seen in the field of popular education in the Philippines even after the ouster of Ferdinand Marcos in 1986. Schugurensky says: "In the Philippines, many popular education groups are still inspired by Freire's ideas, including Education for Life, an organization that coordinates the project "School of the People, School of Life" to promote grassroots leadership formation and community empowerment, and that recognizes Freire's work as one of its main influences." 45 Edicio dela Torre, founder of Education for Life and a former Catholic priest who went underground during the time of Marcos, admits of the influence of Freire and the Danish philosopher, N.F.S. Grundtvig, in his

"Saul Alinsky: Community Organizing and Rules for Radicals," in The Encyclopedia of Informal Education. Accessed March 1, 2013, <http://www.infed.org/thinkers/alinsky.htm>.

${ }^{42}$ G. Silliman, "The Transnational Relations of Philippine NGOs," in Silliman \& Noble, eds., Organizing for Democracy: NGOs, Civil Society, and the Philippines State, 58-59.

${ }^{43}$ Silliman \& Noble, "Introduction," in Organizing for Democracy, 33.

${ }^{44}$ Daniel Schugurensky, Paulo Freire (London \& New York: Continuum International Publishing Group, 2011), 115.

${ }^{45}$ Ibid., 182.

(C) 2013 Franz Giuseppe F. Cortez http://www.kritike.org/journal/issue 13/cortez december2013.pdf ISSN 1908-7330 
thinking on and practice of adult and popular education. ${ }^{46}$ He says that the thoughts of these two educators would be helpful in the shift from "the politics of resistance" appropriate during the time of Marcos' dictatorship to "the politics of participation" in the post-Marcos era when more democratic spaces are available to the people. ${ }^{47}$

In his doctoral dissertation, Edwin Gariguez, a Catholic priest and the current executive secretary of National Secretariat for Social Action of the Philippine Episcopal Commission, sees the significance of adopting Freire's theory and practice of the dialogical method in doing ethnographic research in a Mangyan community in Oriental Mindoro. ${ }^{48}$ He notes how several researchers entering the Mangyan communities perform antidialogical forms of research and thus, objectifying and invading the Mangyan culture along the way. ${ }^{49}$ Gariguez insists that any ethnographic researcher must be guided by the Freirean principle of dialogic process. This only happens when the researcher immerses and involves himself into the life and concerns of the indigenous community. "Entering into research as a dialogical process requires being one with the people or being in solidarity with the people. For Freire, solidarity means a strong commitment to the community guided by decisive involvement to their cause." 50

In the philosophical community, there are only few researchers who produced academic papers on Freire. For example, in the exhaustive listing of philosophical works compiled by Rolando M. Gripaldo, there is only one research about Freire. ${ }^{51}$ It is a masteral thesis by Robert Yabes defended in 1988 at Christ the King Mission Seminary in Quezon City, Philippines. Yabes simply renders an expository account of Freire's pedagogical thoughts mainly seen in Pedagogy of the Oppressed. ${ }^{52}$ Gripaldo admits that there is a probability that some studies are not included in his more than 5,500 listings..$^{53}$ This is true because excluded in Gripaldo's list is a 1991 masteral thesis of Rene Tadle, a philosophy teacher from University of Santo Tomas. In "Paulo Freire's Concept of Revolution," Tadle argues for the

${ }^{46}$ Edicio dela Torre, "Freire and Grundtvig," (blog), August 29, 2007. Accessed September 17, 2012, <http://edicio.wordpress.com/2007/08/29/freire-and-grundtvig/>.

${ }^{47}$ Ibid.

${ }^{48}$ Edwin Gariguez, Articulating Mangyan-Alangans' Indigenous Ecological Spirituality as Paradigm for Sustainable Development and Well-Being (Unpublished Ph.D. Dissertation, Manila: Asian Social Institute, 2008), 60ff.

${ }^{49} \mathrm{Ibid} ., 64$.

${ }^{50}$ Ibid., 66.

51 Rolando Gripaldo, Filipino Philosophy: A Critical Bibliography (1774-1997), 2nd edition (Manila: De La Salle University Press, 2000).

52 Robert Yabes, Paulo Freire's Pedagogy Towards Liberation: An Exposition (Unpublished M.A. thesis, Quezon City: Divine Word Seminary, 1988).

${ }^{53}$ Gripaldo, Filipino Philosophy, viii.

(c) 2013 Franz Giuseppe F. Cortez

http://www.kritike.org/journal/issue 13/cortez december2013.pdf

ISSN 1908-7330

(cc) BY-NC 
possible reconciliation of violent revolution and Christian teaching about love, Freire's position on armed revolution meeting the criteria of traditional ethics' just war principle, and the importance of seeing revolution as a permanent process for social development and total human liberation. ${ }^{54}$ And then in my masteral thesis, I discuss Freire's notion of oppression, conscientization and revolution. ${ }^{55}$ Among other things, I claim that Freire does not readily and uncritically glorify the use of violence in transforming and eradicating the oppressive structures of the society. I note some traces of Freirean thoughts on the importance of reinventing power in postrevolutionary and non-revolutionary societies. ${ }^{56}$

Outside the sphere of strictly philosophical discourses, some articles were written that also draw from the wellspring of Pedagogy of the Oppressed. In the academic discourses of the University of the Philippines (UP) during the 1970s, Freire was being invoked. For example, in a 1977 article written by Alexander Magno, a Filipino academician, he mentions Freire in explaining the relationship of psychology to politics and the society. ${ }^{57}$ For Magno, a crucial part for developing the field of Filipino psychology is for the Filipino psychologist to become aware of his/her role in the political life. The psychologist cannot hide anymore in the cloak of objectivity. "From whatever angle we start our analysis we will end up with a realization that even the most objective academic is confronted with a political choice." 58 Of course, this has a very close affinity to Freire's claim that education, research and science are not neutral; they are always colored by some politics. ${ }^{59}$

In a 1980 paper, Laura Samson explores the possibilities of cultural invasion and domination as embodied in cultural researches. She observes:

Due to its blurred vision of Philippine social reality, most studies on Philippine culture are divorced from a criticism of the basic structure of society and have, instead, encouraged a criticism of the self, and the

54 Rene Tadle, The concept of revolution by Paulo Freire (Unpublished M.A. thesis, Manila: University of Santo Tomas, 1991), 212-217. Tadle published his study in the journal Unitas. See Rene Luis Tadle, "Freire's Methodology and the Revolutionary Process," in Unitas, 66:1 (March 1993): 41-112.

55 Franz Giuseppe Cortez, Paulo Freire's Notion of Oppression, Conscientization and Revolution (Unpublished M.A. thesis, Quezon City, Phils: Christ the King Seminary, 2005).

56 Ibid., 97-99.

57 Alexander R. Magno, "Ilang Paunang Ulat Tungkol sa Sikolohiya at Pulitika," in Mga Katutubong Konsepto at Pamamaraan sa Lipunang Pilipino: Implikasyon sa Edukasyon at Agham Panlipunan (Quezon City: Pambansang Samahan sa Sikolohiyang Pilipino, 1978).

58 "Saan mang aspeto natin simulan ang ating pagsusuri ay hahantong tayo sa isang hangganang nahaharap sa pagpapasyang pulitikal ang pinaka-'obhetibong' akademiko." Ibid., 153.

${ }^{59}$ Freire, The Politics of Education, 103. 
Filipino personality. In this sense, such studies have encouraged striving for improvement among the blind. Unable to see the bars of imprisonment, Filipinos are further reduced to captivity. ${ }^{60}$

Samson suggests cultural research with an element of critique. "By encouraging critical perception of social reality, the study of Philippine culture can be an instrument for deconditioning in the same manner that education as conceived by Paulo Freire can be deconditioning." 61

The familiarity of some UP radical scholars with Freire's thoughts is also reflected in an anthology Mula Tore Patungong Palengke. In an article written by Kenneth Guda, a free-lance journalist, he narrates his experience with Ben, a student from a university in Manila, who went to the mountains for an exposure to a camp of the New People's Army. ${ }^{62}$ From the stories of Ben's experiences in the mountains, Guda sees the dual role of Ben as a teacher of some illiterate kids and at the same time a student of these revolutionaries. Guda sees this dynamics as a concretization of what Pedagogy of the Oppressed would call as education as dialogue with the people. ${ }^{63}$

For his part, Gerry Lanuza, a current sociology professor at Univesity of the Philippines, narrates one case of indigenous education in Zambales. The problem arises when the Aetas face the possible nonrecognition by the Department of Education of Aeta pupils transferring from their indigenous school. Lanuza cites Freire's notion of "fear of liberation" 64 to describe the elitism of the local leaders who do not involve the grassroots in engaging a dialogue with the higher-ups. For Lanuza, these local leaders distrust the people. These leaders also fear that the

${ }^{60}$ Laura Samson, "The Politics of Understanding Philippine Culture," in Allen Aganon \& S. Ma. Assumpta David, RVM, Sikolohiyang Pilipino: Isyu, Pananaw at Kaalaman (Manila: National Book Store, Inc., 1985), 541.

${ }^{61} \mathrm{Ibid} ., 544$.

${ }^{62}$ The New People's Army (NPA) is the armed group of the Communist Party of the Philippines (CPP). Founded in 1968, it launched an armed struggle against the Philippine government for a radical re-structuring of the Philippine society. Up to the present, the communist insurgency in the Philippines is still one of the most daunting tasks for any sitting Philippine president. See International Crisis Group Asia Report No. 202, "The Communist Insurgency in the Philippines: Tactics and Talks," February 14, 2011. Accessed March 15, 2013, $<$ http://www.crisisgroup.org/ /media/Files/asia/south-east-asia/philippines/202\%20The $\% 20$ Communist $\%$ 20Insurgency\% 20in\% 20the\% 20Philippines\%20Tactics\%20and\%20Talks.ashx>.

${ }^{63}$ Kenneth Guda, “A para sa Armalayt: Ilang Tala Hinggil sa Rebolusyonaryong Edukasyon," in Bienvenido Lumbera, Ramon Guillermo, at Arnold Alamon, eds., Mula Tore Patungong Palengke: Neoliberal Education in the Philippines (Quezon City: IBON Foundation Inc., 2007), 331.

${ }^{64}$ The exact term that Freire uses is "fear of freedom." See Freire, Pedagogy of the Oppressed, 31.

(c) 2013 Franz Giuseppe F. Cortez

http://www.kritike.org/journal/issue 13/cortez december2013.pdf

ISSN 1908-7330

(cc) BY-NC 
people become liberated from being totally dependent from them as their patrons. "In the end, the people are reduced to passive clients, the recipients and beneficiaries of doleouts, who cannot make sense of what is going on in the community." 65

There are also some textbooks that deliberately include Freirean themes. In 1980, IBON Foundation, a non-profit research institution, first released a Teacher's Manual on Philippine History. Included on this manual is the famous contrast that Freire made between education for domestication and education for liberation. ${ }^{66} \mathrm{~A}$ more comprehensive attempt of IBON Foundation to bring the concept of progressive education in basic formal classroom setting is reflected in an anthology fittingly entitled Transformative Education. In the article "Classrooms without Walls," Raul Segovia traces the origin and development of the walled classroom which has reached the point when education and schooling has subsumed to the logic of the market and has become less and less a source of hope for emancipatory education. ${ }^{67}$ Inspired by Freire's thoughts, Segovia instead sees the value of political pedagogy that takes place outside the walls of the classrooms and in the voices of those militant leaders in the streets. ${ }^{68}$ In the essay "The Sectoral Movement and the School," Sr. Emelina Villegas narrates the experience of partnerships between sectoral groups fighting for their specific causes and those schools for the rich. The Freirean thoughts become visible as Villegas mentions the words conscientization, dialogue of life through immersion and exposure, and critique of the systems that lead to greater disparity between the rich and the poor. For Villegas, one of the concrete tasks that the schools can do is to sustain the interaction between the school and the community. ${ }^{69}$

In another work, Leonardo Estioko allots some pages to discuss Freire's liberating pedagogy. ${ }^{70}$ The inclusion of Freire in his book shows the intention of bringing into the awareness of present and future teachers that there is such a man as Freire whose pedagogical ideas run in contrast to mainstream educational thoughts and practices. Estioko's other writings on

\footnotetext{
65 Gerry Lanuza, "The Struggle for Cultural and Ethnic Justice in the Age of Neoliberal Capitalism: The Case of Indigenous Education among the Aetas of Botolan, Zambales," in Lumbera, Guillermo, and Alamon, eds., Mula Tore Patungong Palengke: Neoliberal Education in the Philippines, 315. Inc., 1985), 8

${ }^{66}$ IBON Teacher's Manual on Philippine History (Manila: IBON Databank Philippines,

${ }^{67}$ Raul Segovia, "Classrooms Without Walls," in Transformative Education, edited by Antonio Tujan, Jr., (Manila: IBON Foundation, 2004), 24-31.

${ }^{68}$ Ibid., 32.

${ }^{69}$ Sr. Emelina Villegas, "The Sectoral Movement and the School," in Transformative Education, 71.

${ }^{70}$ Fr. Leonardo Estioko, SVD., History of Education: A Filipino Perspective (Manila: Logos Publications, Inc., 1994), 155-159.
}

(C) 2013 Franz Giuseppe F. Cortez http://www.kritike.org/journal/issue 13/cortez december2013.pdf ISSN 1908-7330 
education in the Philippines also show his proclivity for critique of class distinction and its implication to education. ${ }^{71}$

Ranhilio Aquino says that when he is teaching a course on Philosophy of Education, he has always made it a point to start with Freire's Pedagogy of the Oppressed. ${ }^{72}$ He further observes: "...it is disturbing to note that in many of our colleges of teacher-education and even graduate schools, the course 'philosophy of education' is hardly anything more than a survey, often cursory and dilettantist, of different opinions in different books on education. Sadly missed is the struggling with basic issues that is the basic feature of true philosophizing."73 It seems that Aquino finds in Freire's Pedagogy a more relevant way of doing philosophy of education in the Philippines. Furthermore, the fact that Aquino's discussion of Freire can also be found as an introductory text for a course in Philosophy of Man shows the value of the Brazilian's philosophical insights for Aquino's own pedagogy. ${ }^{74}$

But perhaps it is in the work of Amable G. Tuibeo, a philosophy teacher at the Polytechnic University of the Philippines, that Freire has occupied the most towering position. In his work, Tuibeo talks about the nonneutrality of education, the dialogical character of a liberating education and the critique of Philippine educational system among others. ${ }^{75}$ In a fashion reminiscent of Freire and the critical pedagogues, Tuibeo sets the tone of his work by asking the question: For Whom and For What is Education ${ }^{76}$ Then he proceeds to argue that generally speaking, education in the Philippines serves the interest of the few elite so that the task of every educator is to fashion an alternative education that truly advances the interest of the majority of the Filipinos.

\section{Some Observations on this Engagement}

Some observations can be made to this brief survey. First, few Filipino scholars coming from different disciplines such as philosophy, sociology, psychology and politics engage with the thoughts of Freire. Furthermore, some practitioners in the fields of community organizing,

\footnotetext{
${ }^{71}$ See Leonardo Estioko, SVD., Essays on Philippine Education (Manila: Divine Word Publications, 1989), 26-35.

${ }^{72}$ Fr. Ranhilio C. Aquino, To Be Man: Essays on a Philosophy of Man. (N.p.: n.p., c1991), 2.

${ }^{73}$ Ibid., 2.

74 The introductory essay of Aquino's To Be Man, a text for a course in Philosophy of Man, is entitled Paulo Freire and Social Consciousness. See Aquino, To Be Man, 1-19.

75 Amable G. Tuibeo, Philosophy of Education: A New Perspective (Makati City: Grandwater Publications, 2005).

${ }^{76}$ Ibid., i.

(c) 2013 Franz Giuseppe F. Cortez

http://www.kritike.org/journal/issue 13/cortez december2013.pdf

ISSN 1908-7330
}

(cc) BY-NC 
developmental studies, participatory research and militant action would find the relevance of Freire's pedagogical insights in their specific endeavors. Indeed, Freire crosses the boundaries of various disciplines. This is somewhat a validation of what Peter Roberts, a Freirean scholar, says regarding Freire's ideas being "applied by school teachers, academics, adult literacy coordinators, development theorists, church leaders, counselors, psychologists, social workers, health professionals, prison rehabilitation workers, and language learning specialists, among others."77

Second, Freire's thoughts have been applied mainly in nonformal education and community organizing. There have been limited attempts to bring him in the context of formal schooling. Thus, there is an invitation for Filipino critical educators to reinvent Freire for the formal classroom. For example, how can Freirean liberating pedagogy be brought inside a Biology class or a Mathematics class or an Accounting class? This is not an impossible task since there have already been attempts to apply him in subjects such as mathematics, science, language and others. ${ }^{78}$

Third, the survey above shows that there is a limited philosophical engagement with Freire as evidenced by the dearth of philosophical papers about him. What could be the reasons for this? First, the years of Marcos' dictatorship were an era hostile and even fatal for those who entertained radical thoughts. Emerita Quito recounts that immediately after the imposition of Martial Law in September 1972, "the study of Marxism or Maoism was completely abandoned. These courses disappeared from the curriculum, and any literature leaning towards them was confiscated by over-eager officers of the army." 79 In another research, Feorillo Demeterio observes the depletion of philosophical works that criticize the society during the time of Marcos. Demeterio argues that Martial Law indeed "stunted the surge of the critical Filipino philosophy in the early 1970s." 80 Freire's Pedagogy of the Oppressed belongs to writings classified as threatening to any repressive regime. ${ }^{81}$ His name is usually mentioned in

77 Peter Roberts, Education, Literacy, and Humanization: Exploring the Work of Paulo Freire, ed. Henry Giroux (Connecticut: Bergin \& Garvey, 2000), 1.

${ }^{78}$ For example, see Freire for the Classroom: A Sourcebook for Liberatory Teaching, ed. Ira Shor (Portsmouth, NH: Boynton/Cook, c1987).

${ }^{79}$ Emerita Quito, The State of Philosophy in the Philippines (Manila: DLSU Research Center, 1983), 41.

${ }^{80}$ F.P.A. Demeterio III, "Thought and Socio-Politics: An Account of the Late Twentieth Century Filipino Philosophy," HINGOWA: The Holy Rosary Seminary Journal, 8:2 (March 2003), 61.

81 Pedagogy of the Oppressed was written in 1967 to 1968. It was first published into English in 1970. Ironically, it was only published in Brazil in 1975. For some years, the book was considered as contraband by the Brazilian military government. See Paulo Freire, Pedagogy of Hope: Reliving "Pedagogy of the Oppressed," trans. by Robert R. Barr (New York: The Continuum Publishing Corporation, 1995), 62. 
the same breath with Marx, Lenin, Mao and Guevarra. It is not surprising that Freirean scholarship would not flourish openly in a repressive society like that of Marcos' regime.

But what about after the fall of Marcos in 1986? Demeterio's explanation is viable. He talks about the traumas that Filipino philosophy has experienced from Spanish colonization to American colonization to the dictatorship of Marcos. For Demeterio, the effect of these various modes of domination in the history of philosophizing in the Philippines is what he calls a traumatized philosophy. He explains:

Looking back, Filipino philosophy only started to venture into the realm of politics, society, history, economics, and praxiology in general, during the emergence of its critical mode. When this youthful experimentation was cruelly repressed, the trauma delivered affected the overall characteristic of Filipino philosophy and inaugurated its present day characteristic disengagement with the Philippine reality. ${ }^{82}$

Thus, for Demeterio, the brand of philosophizing in the Philippines is generally characterized by repulsion for social critique and a fascination for scholasticism, logic, oriental thought and elaboration of foreign philosophies. Demeterio continues:

If we look at Filipino philosophy today, what we can notice easily is its characteristic shirking away from the political, the social, the historical, and the economic. It has become a philosophy that is dispassionate, cold, and devoid of libido; a philosophy that is lulled by some plenitude of innocuous things, such as the lofty tenets of scholasticism and humanism, the endless mazes of language and logical reasoning, and the exoticism of oriental thought. ${ }^{83}$

An engagement with Freirean educational thought necessarily invites critique of the society. Thus, the lack of interest in Freire fits perfectly with what Demeterio describes as the state of a traumatized Filipino philosophy.

${ }^{82}$ Demeterio, "Thought and Socio-politics," 63.

${ }^{83} \mathrm{Ibid}$.

(c) 2013 Franz Giuseppe F. Cortez

http://www.kritike.org/journal/issue 13/cortez december2013.pdf

ISSN 1908-7330

(cc) BY-NC 
Another possible reason is the growing perception that Marxist discourse has already reached its end especially because of the fall of Communism in the international scene and the mounting unpopularity of the Philippine Left. Freire's Pedagogy is perceived to be a text conceptualized and written especially for revolutionary societies. For many, the Philippine reality does not fall into this category anymore especially with the opening of democratic spaces after the authoritarian regime of Marcos. This is unfortunate because it also means that in the Philippines, Freire has been equated with or even reduced to Pedagogy of the Oppressed. The texts surveyed above would show that most of those who write about Freire or use his pedagogy are mainly consulting Pedagogy and other early writings. His subsequent writings especially during the late 1980s and 1990s are not yet explored. In fact, there are other books that are published posthumously. This provides an opportunity to explore his continuing relevance in an admittedly post-revolutionary era but where domination and oppression paradoxically become more ubiquitous.

\section{A Suggestion for Future Intellectual Engagement with Freire}

As mentioned earlier, there are limited philosophical researches in the Philippines about Freire. But at the same time, because of the wider democratic space where discoursing about transformative education will not send one to jail, there is an opportunity to apply Freire more visibly in the context of formal education. ${ }^{84}$ One possible way of engaging again with this Brazilian radical thinker is for the Filipino student of philosophy to look for the manifestation of Freire's liberating pedagogy in the works and thoughts of Filipino intellectuals especially those who have been working as teachers. This is significant as the philosophical community in the Philippines becomes more aware that these intellectuals (even if they are few) have been contributing in what Demeterio, following Fernando Nakpil-Zialcita, ${ }^{85}$ would call as critical Filipino philosophy, a philosophizing that is essentially involved not just with the "the lofty tenets of scholasticism and humanism, the endless mazes of language and logical reasoning, and the exoticism of oriental thought," 86 but with "a committed critique of our deformed social structure." 87 In fact, by a critical look at these potential

\footnotetext{
${ }^{85}$ Fernando Nakpil-Zialcita, “Mga Anyo ng Pilosopiyang Pilipino,” trans. Nicanor G. Tiongson, in Virgilio Enriquez, Mga Babasahin sa Pilosopiya: Epistemolohiya, Lohika, Wika at Pilosopiyang Pilipino (Manila: Philippine Psychology Research and Training House, 1983), 318.

${ }^{86}$ Demeterio, "Thought and Socio-politics," 63.

${ }^{87}$ F.P.A. Demeterio III, "Defining the Appropriate Field for Radical Intra-State Peace Studies in Filipino Philosophy," in Philippiniana Sacra, 38:13 (2003), 358.
}

${ }^{84}$ Sr. Lourdes Dulay, "Transformative Education and the Syllabus," in Transformative Education, 58.

(C) 2013 Franz Giuseppe F. Cortez http://www.kritike.org/journal/issue 13/cortez december2013.pdf ISSN 1908-7330 
manifestations, the researcher does not only contribute in an important task of elaborating and popularizing the works of Filipino philosophers and intellectuals. ${ }^{88}$ Moreover, he/she may deliberately or accidentally contribute in what Demeterio would call as the urgent need for critique as a form of philosophizing in the Philippines. Thus, "learning again the pathway of critique." 89

Finally, this suggested task should not be interpreted as another effort to import a foreign concept and shove it into the throat of the Filipino student to be swallowed passively and digested uncritically. Rather, it should be seen as a great opportunity for a simultaneous act of critique and rediscovery of a theory and practice that has risen amidst an experience of oppression-an experience that is certainly shared by the Philippine society and the reality of Freire's Brazil. Kozol calls this "shared heritage of servitude" while Freire himself speaks about the existence of a "Third World in the First World"90 to emphasize the ubiquitous character of oppression. As Demeterio would say: "Though critical philosophy is similarly alien in origin, through its being an immanent reflection on the real world and through its simple engagement with Philippine reality, it can easily be appropriated by our Filipino philosophers, professors and students of philosophy." 91 In other words, for Demeterio, borrowing from outside is never a primary issue. What is important is that these foreign philosophies find their way into the very lived experiences of the Filipinos. "In simpler words, it is fine if Filipino philosophy students decide to study foreign philosophies as long as they will not forget that ultimately the purpose of these foreign philosophies is to provide conceptual tools for all of us to grapple with our own philosophical problems." ${ }^{92}$

Department of Philosophy, University of Santo Tomas, Philippines

\section{References}

Aquino, Fr. Ranhilio C., To Be Man: Essays on a Philosophy of Man (N.p.: n.p., 1991).

\footnotetext{
${ }^{88}$ In his textbook on thesis writing for philosophy students, Demeterio encourages a study that explores the philosophical contributions of Filipino intellectuals. See Feorillo Demeterio, Manual for a Thesis Work in Philosophy, $2^{\text {nd }}$ ed. (N.p.: n.p., c2003), 13.

${ }^{89}$ Demeterio, "Thought and Socio-politics," 72-73.

90 See Ana Freire and Paolo Vittoria, "Dialogue on Paulo Freire," in Interamerican Journal of Education for Democracy, 1:1 (2007), 100. Accessed August 14, 2012, $<$ http://scholarworks.iu.edu/journals/index.php/ried/article/view/115/195>.

${ }^{91}$ Demeterio, "Thought and Socio-Politics," 68.

${ }^{92}$ Demeterio, Manual for a Thesis Work, 13.

(c) 2013 Franz Giuseppe F. Cortez

http://www.kritike.org/journal/issue 13/cortez december2013.pdf

ISSN 1908-7330
}

(cc) BY-NC 
Brookfield, Stephen D., "Transformative Learning as Ideology Critique," in Learning as Transformation: Critical Perspectives on a Theory in Progress (San Francisco, Calif.: Jossey-Bass, 2000).

Carroll, John J., S.J., "Philippine NGOs Confront Urban Poverty," in Organizing for Democracy: NGOs, Civil Society, and the Philippines State (Quezon City: Ateneo de Manila University Press, 1998).

Collins, Denis E., "From Oppression to Hope: Freire's Journey toward Utopia," in Anthropology \& Education Quarterly, 29:1 (March 1998), 115-124.

Paulo Freire: His Life, Works and Thoughts (New York: Paulist Press, 1977).

Constantino-David, Karina, "From the Present Looking Back: A History of Philippine NGOs," in Organizing for Democracy: NGOs, Civil Society, and the Philippines State (Quezon City: Ateneo de Manila University Press, 1998).

Cortez, Franz Giuseppe F., Paulo Freire's Notion of Oppression, Conscientization and Revolution (Unpublished M.A. thesis, Quezon City: Christ the King Seminary, 2005).

Dela Torre, Edicio, "Freire and Grundtvig," (blog), August 29, 2007. Accessed September 17, 2012, $<$ http://edicio.wordpress.com/2007/08/29/freire-and-grundtvig/>.

Demeterio, F.P.A. III, "Defining the Appropriate Field for Radical IntraState Peace Studies in Filipino Philosophy," in Philippiniana Sacra, 38:13 (2003), 345-360.

Manual for a Thesis Work in Philosophy, $2^{\text {nd }}$ ed. (N.p.: n.p., c2003).

"Thought and Socio-politics: An Account of the Late Twentieth Century Filipino Philosophy," in HINGOWA: The Holy Rosary Seminary Journal, 8:2 (March 2003), 45-73.

Dulay, Lourdes, ICM, "Transformative Education and the Syllabus," in Transformative Education (Manila: IBON Foundation, 2004).

Elias, John L., Paulo Freire: Pedagogue of Liberation (Florida: Krieger Publishing Company, 1994).

Estioko, Leonardo R., SVD., Essays on Philippine Education (Manila: Divine Word Publications, 1989).

History of Education: A Filipino Perspective (Manila: Divine Word Publications, 1994).

Freire, Ana Maria Araujo \& Paolo Vittoria, "Dialogue on Paulo Freire," in Interamerican Journal of Education for Democracy, 1:1 (September 2007), 97-117.

Freire, Paulo, "Conscientizing as a Way of Liberating," in Third World Liberation Theologies: A Reader (New York: Orbis Books, 1986).

(C) 2013 Franz Giuseppe F. Cortez

http://www.kritike.org/journal/issue 13/cortez december2013.pdf

ISSN 1908-7330 
Cultural Action for Freedom (Cambridge: Harvard Educational Review, 2000).

Education for Liberation: Addresses by Paulo Freire and Critical Reflections on Indian Education (Bangalore: Ecumenical Christian Centre Publication, 1975).

Pedagogy of Freedom: Ethics, Democracy and Civic Courage, trans. by Patrick Clarke (Maryland: Rowman \& Littlefield Publishers, Inc., 1998).

Pedagogy of Hope: Reliving Pedagogy of the Oppressed, trans. by Robert R. Barr (New York: The Continuum Publishing Corporation, 1995).

Pedagogy of the City (New York: Continuum Press, 1993).

Pedagogy of the Oppressed, trans. by Myra Bergman Ramos

(New York: The Continuum Publishing Corporation, 1984).

The Politics of Education: Culture, Power, and Liberation, trans. by Donaldo Macedo (Connecticut: Bergin \& Garvey Publishers, Inc., 1985).

Freire, Paulo, and Donaldo Macedo, Literacy: Reading the Word \& the World (Massachusetts: Bergin \& Garvey Publishers, Inc., 1987).

Freire, Paulo, and Ira Shor, A Pedagogy for Liberation: Dialogues on Transforming Education (London: MacMillan Education Ltd., 1987).

Gariguez, Edwin A., Articulating Mangyan-Alangans' Indigenous Ecological Spirituality as Paradigm for Sustainable Development and Well-Being (Unpublished Ph.D. Dissertation, Manila: Asian Social Institute, 2008).

Giroux, Henry A., Teachers as Intellectuals: Towards a Critical Pedagogy of Learning (Massachusetts: Bergin \& Garvey, 1988).

Glass, Ronald David, "On Paulo Freire's Philosophy of Praxis and the Foundations of Liberation Education," in Educational Researcher, 30:2 (March 2001), 15-25.

Gripaldo, Rolando M., Filipino Philosophy: A Critical Bibliography (1774-1997). $2^{\text {nd }}$ edition (Manila: De La Salle University Press, 2000).

Guda, Kenneth Roland A., "A para sa Armalayt: Ilang Tala Hinggil sa Rebolusyonaryong Edukasyon," in Mula Tore Patungong Palengke: Neoliberal Education in the Philippines (Quezon City: IBON Foundation Inc., 2007).

IBON Teacher's Manual on Philippine History (Manila: IBON Databank Philippines, Inc., 1985).

International Crisis Group Asia Report No. 202, "The Communist Insurgency in the Philippines: Tactics and Talks," February 14, 2011. Accessed March 15, 2013, <http://www.crisisgroup.org>.

(c) 2013 Franz Giuseppe F. Cortez http://www.kritike.org/journal/issue 13/cortez december2013.pdf ISSN 1908-7330 
Joaquin, Nick, Manila, My Manila: A History for the Young (Manila: The City of Manila, 1990).

Kincheloe, Joe L., Critical Pedagogy Primer. $2^{\text {nded. }}$ (New York: Peter Lang Publishing Inc., 2008).

Kozol, Jonathan, Foreword to Pedagogy in Process: The Letters to Guinea-Bissau (New York: The Seabury Press, 1978).

Lanuza, Gerry, "The Struggle for Cultural and Ethnic Justice in the Age of Neoliberal Capitalism: The Case of Indigenous Education among the Aetas of Botolan, Zambales," in Mula Tore Patungong Palengke: Neoliberal Education in the Philippines (Quezon City: IBON Foundation Inc., 2007).

Lopa, Margarita A., Singing the Same Song: Reflections of Two Generations of NGO Workers in the Philippines (Quezon City: ANGOC \& PHILDHRRA, 1995).

Mackie, Robert ed., Literacy and Revolution: The Pedagogy of Paulo Freire (New York: Continuum Publishing, 1981).

Magno, Alexander R., "Ilang Paunang Ulat Tungkol sa Sikolohiya at Pulitika," in Mga Katutubong Konsepto at Pamamaraan sa Lipunang Pilipino: Implikasyon sa Edukasyon at Agham Panlipunan (Quezon City: Pambansang Samahan sa Sikolohiyang Pilipino, 1978).

Nakpil-Zialcita, Fernando, "Mga Anyo ng Pilosopiyang Pilipino," trans. by Nicanor G. Tiongson, in Mga Babasahin sa Pilosopiya: Epistemolohiya, Lohika, Wika at Pilosopiyang Pilipino (Manila: Philippine Psychology Research and Training House, 1983).

Quito, Emerita S., "Ang Sariling Wika, Ang Pilosopiya, at ang Mga Tao," in Mga Babasahin sa Pilosopiya: Epistemolohiya, Lohika, Wika at Pilosopiyang Pilipino (Manila: Philippine Psychology Research and Training House, 1983).

Roberts, Peter, Education, Literacy, and Humanization: Exploring the Work of Paulo Freire (Connecticut: Bergin \& Garvey, 2000).

Samson, Laura, "The Politics of Understanding Philippine Culture," in Sikolohiyang Pilipino: Isyu, Pananaw at Kaalaman (Manila: National Book Store, Inc., 1985).

Schugurensky, Daniel, Paulo Freire (London: Continuum International Publishing Group, 2011).

Seal, Mike, "Saul Alinsky: Community Organizing and Rules for Radicals," in The Encyclopedia of Informal Education. Accessed March 1, 2013, $<$ http://www.infed.org/thinkers/alinsky.htm>.

Segovia, Raul, "Classrooms without Walls," in Transformative Education (Manila: IBON Foundation, 2004).

Shor, Ira ed., Freire for the Classroom: A Sourcebook for Liberatory Teaching (Portsmouth, NH: Boynton/Cook, 1987).

(c) 2013 Franz Giuseppe F. Cortez http://www.kritike.org/journal/issue 13/cortez december2013.pdf ISSN 1908-7330 
Silliman, G. Sidney, "The Transnational Relations of Philippine NGOs," in Organizing for Democracy: NGOs, Civil Society, and the Philippines State (Quezon City: Ateneo de Manila University Press, 1998).

Tadle, Rene Luis, The Concept of Revolution by Paulo Freire (Unpublished M.A. Thesis, Manila: University of Santo Tomas, 1991). "Freire's Methodology and the Revolutionary Process," in Unitas, 66:1 (March 1993), 41-112.

Taylor, Paul V., The Texts of Paulo Freire (Philadelphia: Open University Press, 1993).

Tiongson, Nicanor, "What is Philippine Drama?," in IBON Teacher's Manual on Philippine History (Manila: IBON Databank Philippines, Inc., 1985).

Tuibeo, Amable G., Philosophy of Education: A New Perspective (Makati City: Grandwater Publications and Research Corporation, 2005).

Ty, Rey, "Where Moses, Jesus, Mary, Marx, and Freire Share Rice and Fish at the Table: Post-Colonial Christians, Theology of Struggle, and National Liberation in the Philippines," in Proceedings of 27th Annual Midwest Research-to-Practice Conference in Adult, Continuing, Community and Extension Education (Bowling Green: Western Kentucky University). Accessed August 24, 2012, $<$ http://academia.edu/ Documents/in/Theology_of_Struggle $>$.

Villegas, Emelina, ICM, "The Sectoral Movement and the School," in Transformative Education (Manila: IBON Foundation, 2004).

Yabes, Robert P., Paulo Freire's Pedagogy Towards Liberation: An Exposition (Unpublished M.A. Thesis, Quezon City: Divine Word Seminary, 1988). 